\title{
Effect of the inclusion of scent leaf (ocimum gratissimum) in diet on growth and haematology of growing rabbits
}

${ }^{1}$ Buba, W., ${ }^{2}$ Duru, S., ${ }^{2}$ Metemilola, J., ${ }^{3}$ Uchendu, C. and ${ }^{1}$ Iyiola-Tunji, A. O. ${ }^{1}$ National Agricultural Extension and Research Liaison Services, Ahmadu Bello University, Zaria.

${ }^{2}$ Animal Science Department, Ahmadu Bello University, Zaria, Kaduna State ${ }^{3}$ Department of Pharmacology and Toxicology, Faculty of Veterinary Medicine, Ahmadu Bello University, Zaria.

Corresponding Author: bubawahe@gmail.com Phone number: +2348065399885

\section{Abstract}

The effect of scent leaf (Ocimum gratissimum) as feed additive in rabbit diet on growth and hematological parameters of rabbits was investigated using a number of 24 non-descript rabbits in an eight (8) weeks feeding trial. Four experimental diets were formulated to contain 0.0, 2.0, 4.0 and 6.0 g scent leaf (SL) per $\mathrm{kg}$ of feed. The diets were randomly assigned to four treatment groups of 6 rabbits per treatment in a completely randomized design (CRD) experiment. Feed and water were offered ad libitum. Feed intake and weight gain was taken and used to calculate other growth performance parameters while blood sample $(2 \mathrm{ml})$ was collected aseptically between 6:30 and 7:30 am from three rabbits per treatment and transferred into heparinised tubes which was used to determine the haematological parameters ( $P C V, H b$, red blood cells and white blood cells). The results showed that there was significant $(P<0.05)$ differences in body weight gain and feed conversion ratio $(F C R)$ across the four (4) treatment groups with treatment group fed scent leaf at $4.0 \mathrm{~g} / \mathrm{kg}$ diet having the highest weight gain and the best FCR. There was also significant difference $(P<0.05)$ in albumin and cholesterol levels. Haematological parameters showed significant difference $(P<0.05)$ across the treatment groups with treatment group fed $2.0 \mathrm{~g}$ scent leaf having the lowest white blood cell $\left(8.00 \times 10^{12} / \mathrm{L}\right)$. In conclusion treatment group fed $4.0 \mathrm{~g}$ scent leaf gave the best result in terms of weight gain and FCR.

Keywords: Scent leave, Rabbit, growth, haematology

\section{Introduction}

Phytogenic feed additives are defined as herbal substances included in the feed for the purpose of enhancing production and quality of animal products (Václavková et al., 2010). Phytogenic feed additives comprise of a wide variety of herbs, spices, and essential oils. These feed additives help in enhancing the taste and improving the flavor of feed. Phytogenic feed additives are believed to have positive effects on digestion and intestinal health. Some of the beneficial effects of phytogenic feed additives are their ability to prevent digestive disturbances, improve feed utilization and enhance animal performance (Krieg et al., 2009; Karaskova et al., 2015).

This class of additive is gaining high interest especially in livestock sector due to the ban on the use of antibiotics as growth promoters in Europe in 1999, and also the high cost of synthetic drugs and their residual effects on livestock and their products (Mirzaei et al., 2012). These plant-derived products are natural, less toxic, residue free and are thought to be ideal feed additives in animal production (Hashemi et al., 2010. The use of phytogenics in feed production can restrict 
Effect of the inclusion of scent leaf (ocimum gratissimum) in diet on growth and haematology of growing rabbits

growth of fungi; production of mycotoxins in animal feeds and also reduces the need of use of drugs. Feeding phytogenics products do not require any withdrawal periods as reported by (Marcincak et al., 2010).

Materials which can be used as phytogenic feed additives include herbs, non woody plants known to have medicinal properties, spices with intensive smell or taste which include: mint, sage, thyme, garlic, scent leaf etc. Scent leaf (Ocimum gratissimum) is an herbaceous perennial grass and it is widely distributed throughout the tropics widely naturalized in many regions (Nnabugwu, 2010; Odoemelam, et al., 2012). It is also a known traditional medicinal plant used in curing different ailments, (Onajobi, 1986; Kokwaro, 1993). Some chemical compounds and active ingredients from this plant that makes it exhibit strong antimicrobial properties include Eugenol, Cinamate, Camphor and Thymol (Adebolu and Oladimeji, 2005; Matasyoh et al., 2007). However, available information on the use of Ocimum gratissimum as feed ingredient in poultry diets is still scanty. Currently, the demand for these plants and their derivatives has increased because they are natural, eco-friendly and generally recognized as safe products. Therefore, phytogenic plants and their extracts have the potential to become new generation substances for animal nutrition and health. Therefore, the objective of the study is to determine the effect Ocimum gratissimum as phytogenic feed additives on performance of growing rabbits.

\section{Materials and methods Experimental site}

The study was conducted at the rabbitry unit of the Skill Acquisition and Development Centre of National Agricultural Extension and Research Liaison Service (NAERLS), Ahmadu Bello University, Zaria. Zaria is located within the Northern Guinea Savannah Zone of Nigeria at latitude $11^{\circ} 09^{\prime} 06^{\prime \prime} \mathrm{N}$ and longitude $7^{0} 38^{\prime} 55^{\prime \prime} \mathrm{E}$, at an altitude of $706 \mathrm{~m}$ above sea level (GPS 2014). The area falls within the Northern-Guinea Savannah Zone having an average annual rainfall of $1100 \mathrm{~mm}$, which starts from late April or early May to mid-October. The maximum temperature varies from $26^{\circ} \mathrm{C}$ to $35^{\circ} \mathrm{C}$ depending on the season while the mean relative humidity during harmattan period and the wet season are 21 and $72 \%$, respectively.

Source and preparation of scent leaf (Ocimum gratissimum)

Fresh leaves of Ocimum gratissimum were purchased fresh from Sabon Gari Market, Zaria. The leaves were chopped and airdried. The dried leaves were then ground and stored in bags properly.

\section{Source of Rabbits}

A total of twenty four (24) weaned nondescript rabbits of five weeks old were purchased from a commercial rabbit seller in Samaru market Zaria, Kaduna State.

\section{Management of experimental rabbits}

The rabbits were quarantined for 1 week. The rabbits were raised in individual cages and also placed on the experimental diet at different levels of inclusion of scent leaf. The rabbits were weighed before the commencement of the study. They were balanced for weight and randomly allocated to the four dietary treatments in a Completely Randomized Design having 6 replicates per treatment. Feed and water was given to the animals on daily basis for 8 weeks.

\section{Experimental Diets}

A basal diet was prepared and scent leaf was included at different levels of 0.0, 2.0, 4.0 and $6.0 \mathrm{~g}$ per $\mathrm{kg}$ of feed. Other ingredients in the feed are as shown in table 1 and table 2 shows the nutrient composition of the experimental diet. 
Buba, Duru, Metemilola, Uchendu and Iyiola-Tunji

Table 1: Composition of formulated diet

\begin{tabular}{ll}
\hline Ingredients & Percentage \\
\hline Maize & 25.00 \\
Soyabean meal & 5.00 \\
Maize offal & 15.00 \\
Brewers dried grains & 25.00 \\
Groundnut cake & 12.00 \\
Blood meal & 2.00 \\
Rice offal & 12.00 \\
Bone meal & 3.00 \\
Table salt & 0.25 \\
Premix* & 0.25 \\
L-Lysine & 0.25 \\
DL-Methionine & 0.25 \\
Total & $\mathbf{1 0 0}$ \\
\hline *Provide per kilogram of diet: vitamin A, 10000 IU (retinyl acetate); cholecalciferol, 3000 IU; vitamin E, \\
8.0 IU (DL -a-tocopheryl acetate); K, 2.0 mg; thiamine, 2.0mg; pyridoxine, 1.2mg; cyanocobalamin, \\
0.12mg; niacin, 1.0mg; fol ic acid, 0.6mg; choline chloride, 500mg; Fe, 60mg; Mn, 100mg; Cu, 8.0mg; \\
Zn, 50mg; Co, 0.45mg; I, 2.0mg; Se, 0.1mg
\end{tabular}

Table 2: Nutrient Composition of Experimental Diet

\begin{tabular}{ll}
\hline Nutrients & \% \\
\hline Dry matter (\%) & 94.63 \\
Crude protein (\%) & 16.02 \\
Crude fibre (\%) & 14.11 \\
Ether extract (\%) & 3.91 \\
Ash (\%) & 10.21 \\
Nitrogen free extract (\%) & 50.38 \\
Metabolize energy (Kcal/kg) & 2607.80 \\
\hline
\end{tabular}

\section{Measurement of growth performance}

Feed consumption and body weight of the rabbits were recorded weekly. Body weight gain was calculated as the difference between the final weight and the initial weight. Feed conversion was calculated as the ratio between feed intake and weight gain.

\section{Haematological analysis}

At the end of the experiment (8 weeks), blood sample $(2 \mathrm{ml})$ from each replicate was collected aseptically from the marginal ear vein and the blood sample was transferred into well labelled heparinised tubes which was used to determine the haematological parameters $(\mathrm{PCV}, \mathrm{Hb}$, red blood cells and white blood cells) at Faculty of Veterinary Medicine, Ahmadu Bello University, Zaria using Abbott
Haematological Analyser (Cell-Dyn $1700 \AA$, Abbott Park, Illinois, U.S.A.).

\section{Evaluation of Albumin and cholesterol}

Blood samples were taken at slaughter time from each rabbit into heparinized tubes, which was taken to the Department of Histopathology, Ahmadu Bello University Teaching Hospital, Shika, Zaria for the determination of albumin and cholesterol levels which was calorimetrically determined using ELISA multiplex commercial kits (Pfizer Animal Health, New York) following the steps as described by manufactures.

\section{Statistical analysis}

Data were subjected to the analysis of variance (ANOVA) using the general linear model procedure of SAS (2001). Significant differences among treatment 
Effect of the inclusion of scent leaf (ocimum gratissimum) in diet on growth and haematology of growing rabbits

means was separated using the Duncan's Multiple Range Test in the SAS, version 9.0 package.

\section{Results}

Table 3 shows the phytochemical analysis of scent leaf. The feed intake and growth performance of the rabbits fed Ocimum gratissimum are presented in table 4 . There were significant increase $(\mathrm{P}<0.05)$ in the feed intake and final body weight. The lowest $(3441.3 \mathrm{~g})$ feed intake was recorded in the control group while no statistical difference observed in treatment group fed 2.0 and $4.0 \mathrm{~g} / \mathrm{kg}$ Ocimum gratissimum leaves. The feed intake of treatment group fed $6.0 \mathrm{~g} / \mathrm{kg}$ Ocimum gratissimum leaves was statistically similar to treatment groups fed 2.0 and $4.0 \mathrm{~g} / \mathrm{kg}$.

Rabbits fed $4.0 \mathrm{~g} / \mathrm{kg}$ feed had the highest $(851.17 \mathrm{~g})$ weight gain while the least $(641.6 \mathrm{~g})$ weight gain is in the control group. The best feed conversion ratio (2.79) was recorded in the treatment group fed $4.0 \mathrm{~g} / \mathrm{g}$ Ocimum gratissimum while the highest (3.08) feed conversion ratio was recorded in the control group.

No mortality was recorded in all the treatment groups during the experimental period.

Table 3: Phytochemical analysis of scent leaf (Ocimum gratissimum)

\begin{tabular}{llc}
\hline Phytochemicals & Test & Results \\
\hline Carbohydrate & Molish test & ++ \\
Saponin glycosides & Frothing test & + \\
Phenolic compounds & Ferric chloride test & + \\
Flavonoids & NaOH test & ++ \\
Tannin & Ferric chloride test & + \\
Cardiac glycoside & Kellakiliani test & ++ \\
Alkaloids & Wargner's test & ++ \\
Anthraces derivatives & Bontrager's test & - \\
\hline
\end{tabular}

Key: $++=$ highly positive, $+=$ positive, $-=$ negative

Table 4: Effect of Scent leaf (Ocimum gratissimum) fed to rabbits on growth performance

\begin{tabular}{llllll}
\hline Parameters & \multicolumn{5}{c}{ Treatments } \\
\cline { 2 - 6 } & $\mathbf{T 1}(\mathbf{0 . 0 g})$ & $\mathbf{T 2}(\mathbf{2 . 0 g})$ & $\mathbf{T 3}(\mathbf{4 . 0 g})$ & $\mathbf{T 4}(\mathbf{6 . 0 g})$ & SEM \\
\hline Initial body weight (g/rabbit) & 477.40 & 470.67 & 476.83 & 483.83 & 41.1 \\
Final body weight (g/rabbit) & $1119.0^{\mathrm{c}}$ & $1202.5^{\mathrm{b}}$ & $1328.0^{\mathrm{a}}$ & $1223.8^{\mathrm{b}}$ & 25.1 \\
Total body weight gain(g/rabbit) & $641.6^{\mathrm{c}}$ & $731.83^{\mathrm{b}}$ & $851.17^{\mathrm{a}}$ & $739.97^{\mathrm{b}}$ & 25.1 \\
Total feed intake (g/rabbit) & $3441.3^{\mathrm{b}}$ & $3760.7^{\mathrm{a}}$ & $3705.7^{\mathrm{a}}$ & $3597.7^{\mathrm{ab}}$ & 117.5 \\
Feed conversion ratio & $3.08^{\mathrm{b}}$ & $3.13^{\mathrm{a}}$ & $2.79^{\mathrm{d}}$ & $2.94^{\mathrm{c}}$ & 0.2 \\
Mortality (\%) & 0.0 & 0.0 & 0.0 & 0.0 & 0.0 \\
\hline
\end{tabular}

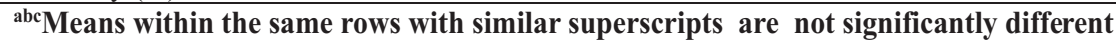

Table 5 shows the haematological parameters of the experimental rabbits. The haemoglobin $(\mathrm{Hb})$ concentration, packed cell volume (PCV) and white blood cells $(\mathrm{WBC})$ had significant $(\mathrm{P}<0.05)$ difference across the treatment. No statistical difference was observed in treatment groups fed 0.0, 2.0 and $4.0 \mathrm{~g} / \mathrm{kg}$ scent leave in terms of $\mathrm{PVC}$ and $\mathrm{Hb}$. WBC was higher $\left(11.10 \times 10^{12} / \mathrm{L}\right)$ in treatment group fed $4.0 \mathrm{~g} / \mathrm{kg}$ scent leaves while the least was recorded in the treatment group fed $6.0 \mathrm{~g} / \mathrm{kg}$ scent leaves.

Table 6 shows biochemical parameters of the experimental rabbits. Significant $(\mathrm{P}<0.05)$ differences were recorded among the treatment means in albumin. Albumin level was higher $(51.67 \mathrm{~g} / \mathrm{dl})$ in treatment 


\section{Buba, Duru, Metemilola, Uchendu and Iyiola-Tunji}

group fed $4.0 \mathrm{~g} / \mathrm{kg}$ scent leaves while the least is in the control group. Higher levels $(3.77 \mathrm{mg} / \mathrm{DL})$ of cholesterol was recorded in the control group while no significant
$(\mathrm{P}>0.05)$ difference was observed in treatment group fed 2.0, 4.0 and $6.0 \mathrm{~g} / \mathrm{kg}$ scent leaves. No significant difference observed in terms of total protein in all the treatment groups.

Table 5: Effect of Scent leaf (Ocimum gratissimum) fed to rabbits on haematological parameters

\begin{tabular}{lcllll}
\hline Parameters & & \multicolumn{3}{c}{ Treatments } \\
& T1 $(\mathbf{0 . 0 g} / \mathbf{k g})$ & $\mathbf{T 2}(\mathbf{2 . 0 g} / \mathbf{k g})$ & $\mathbf{T 3}(\mathbf{4 . 0 g} / \mathbf{k g})$ & $\mathbf{T 4}(\mathbf{6 . 0} / \mathbf{k g g})$ & SEM \\
\hline $\mathrm{PCV}(\%)$ & $33.00^{\mathrm{a}}$ & $32.33^{\mathrm{a}}$ & $33.33^{\mathrm{a}}$ & $28.33^{\mathrm{b}}$ & 1.8 \\
$\mathrm{Hb}(\mathrm{g} / \mathrm{dl})$ & $10.97^{\mathrm{a}}$ & $10.77^{\mathrm{a}}$ & $11.07^{\mathrm{a}}$ & $9.40^{\mathrm{b}}$ & 0.6 \\
$\mathrm{WBC}\left(\mathrm{x} 10^{12} / \mathrm{L}\right)$ & $8.80^{\mathrm{b}}$ & $8.00^{\mathrm{bc}}$ & $11.10^{\mathrm{a}}$ & $7.27^{\mathrm{c}}$ & 0.5 \\
\hline
\end{tabular}

${ }^{\mathrm{abc}}$ Means within the same rows with similar superscripts are not significantly different

Table 6: Effect of Scent leaf (Ocimum gratissimum) fed to rabbits on blood biochemical parameters Inclusion levels (g/kg diet) Parameters

\begin{tabular}{llll} 
& Albumin $(\mathbf{g} / \mathbf{d l})$ & Cholesterol $(\mathbf{m g} / \mathbf{d L})$ & Total protein $(\mathbf{g} / \mathbf{d L})$ \\
\hline 0.0 & $43.67^{\mathrm{b}}$ & $3.77^{\mathrm{a}}$ & $5.80^{\mathrm{a}}$ \\
2.0 & $39.00^{\mathrm{c}}$ & $3.03^{\mathrm{b}}$ & $5.87^{\mathrm{a}}$ \\
4.0 & $51.67^{\mathrm{a}}$ & $3.47^{\mathrm{b}}$ & $5.67^{\mathrm{a}}$ \\
6.0 & $45.67^{\mathrm{b}}$ & $3.53^{\mathrm{b}}$ & $5.67^{\mathrm{a}}$ \\
SEM & 2.7 & 0.3 & 0.2 \\
\hline
\end{tabular}

${ }^{\mathrm{abc}}$ Means within the same columns with similar superscripts are not significantly different

\section{Discussion}

The increase in the weight gain observed in the treatment groups fed scent leaves could be due to positive effect of scent leaves on feed quality and health of animals as well as increase in the feed consumption of the birds. This is in agreement with Mcmullin (2000) that observed that most herbs and extracts of spices work as growth promoters by killing parasites that hinder digestibility and growth performance of birds. Also, According to Adepoju and Oyewole, (2008), Ocimum gratissimum leave is rich in minerals and vitamins which helps stimulate appetite when fed to rabbits. Ibrahim et al., (1997) reported that Ocimum gratissimum could be used for spicing and seasoning of food and as such could increase the palatability of food. The aroma from the Ocimum gratissimum leaves which are mainly eugenol methyl cinnamate, camphor and thymol (Nakamura et al., 1999), might have some feed digestive properties that increase the appetite of the animals. Also the increase in growth noticed in the treatment group fed $4.0 \mathrm{~g} / \mathrm{kg}$ Ocimum gratissimum could be due to the absorption of fat which lead to more gain when compared with control group as reported by (El-Shenawi 1992)

Also the better feed conversion ratio observed in the Ocimum gratissimum treated groups could be attributed to their positive effects on nutrient digestibility as reported by (Madrid et al., 2003 and Hernandez et al., 2004). Similarly Ibrahim et al., (2000) reported an increase in feed conversion when male weaned $\mathrm{New}$ Zealand White rabbits fed diets supplemented with Peppermint leaves at $0.5 \%$.

The mean values of Haemoglobin, PCV, and WBC obtained from all the experimental rabbits are within the range of haematological values of rabbits. The difference observed in the mean WBC values of rabbits fed $4.0 \mathrm{~g} / \mathrm{kg}$ Ocimum gratissimum implies differences in the 
Effect of the inclusion of scent leaf (ocimum gratissimum) in diet on growth and haematology of growing rabbits

intrinsic body defense system as reported by (Ganomg, 1991). Similar result was also reported by Ibrahim et al. (2000) that found significant increase in $\mathrm{RBC}$ count, $\mathrm{Hb}$ and $\mathrm{PCV} \%$ in males of New Zealand rabbits fed diet for eight weeks supplemented with $0.5 \%$ of peppermint

The reduction in cholesterol could be the effect of flavonoids which are found in Ocimum gratissimum and are known to reduce cholesterol level. The reduced level of cholesterol observed in the Ocimum gratissimum treated groups agrees with the report of Rai et al. (1997) which showed that the administration of Ocimum gratissimum reduced serum total cholesterol in rabbits Similarly, E1Manylawi et al. (2005) reported that total lipid and cholesterol of growing rabbits fed diets containing 6 or $9 \%$ of spearmint and geranium by-product were significantly decreased.

\section{Conclusion and recommendation}

The results of this study revealed that Ocimum gratissimum leaf extracts can be used to improve growth performance and some blood components of rabbits. The result also provided a hope to the natural and safe alternative to the antibiotics drugs that are commonly used in many developing countries like Nigeria. It is therefore recommended that inclusion of scent leaf in diet of rabbits at $4 \mathrm{~g} / \mathrm{kg}$ feed can improve their growth performance and also reduce the cholesterol level.

\section{References}

Adebolu, T. T. and Oladumeji, S. A. 2005. Antimicrobial activity of Ocimum gratissimum on selected diarrhea causing bacteria in South Western Nigeria. African Journal of Biotechnology 4(7): 682-684.

Adepoju, O. T and Oyewole, E. O 2008.
Nutritional importance and Micronutrients Potentials of nonconventional indigenous green leafy vegetable from Nigeria. Agricultural Journal 3 (5): 362-365.

El-Manylawi, M. A., Ibrahim, M. R. M., Fatma, G. and Walaa, A. 2005. Performance of growing rabbits fed diets containing Geranium and Spearmint By-products. Egyptian Journal Rabbit Science; Volume 15(1):13-26.

El-Shenawi, A. 1992. Medicate by herbal. Textbook, El-Eman Library, ElMansoura, Egypt.

Ganomg, J. E. 1991. A Review of Medical Physiology. Lange Medical Publication.pp.115.

GPS Global Positioning System, (2014)

Hashemi, S. R and Davoodi, H. 2010. Phytogenics as new class of feed additive in poultry industry. Journal of Animal and Veterinary Advances 9 (17):2295-2304.

Hernandez, F., Madrid, J., Garcia, V., Orengo, J. and Megias, M. D. 2004. Influence of two plant extracts on broiler performance, digestibility, and digestive organ size. Poultry Science; 83: 169-174.

Ibrahim, A. M., El-Ghamry, A. A. and El-Mallah, G. M. 2000. Effect of some medicinal plants of labiatae family as feed additives on growth and metabolic changes of rabbits. Egyptian Journal Rabbit Science; 10 (1):105-120.

Ibrahim, M. B., Owonbi, M. O. and Onaolap O. J.A. 1997. Effect of the extracts of leaf, stem and root 6571 bark of Anogesisus leiocarpus on S. and root bark $S$. Spyogenes NCTC. 8198 E. Coli NCTC. 1048 and P Vulgaris NCTS 4638. Journal of Pharmacollogy Research 
Develpment. 21, 20-20.

Karaskova, K., Suchy, P. and Strakova, E. 2015. Current use of phytogenic feed additives in animal nutrition: a review. Czech Journal of Animal Science, 60(12):521-530

Kokwaro, J. O. 1993. Medicinal Plants of Eastern Kampala, Nairobi and Daressalaam Eastern Africa Literature Bureau: Pp. 106-115.

Krieg R., Vahjen, W., Awad, W., Sysel, M., Kroeger, S., Zocher, E., Hulan, H.W., Aarndt, G. and Zentek, J. 2009. Performance, digestive disorders and the intestinal microbiota in weaning rabbits are affected by a herbal feed additive. World Rabbit Science, 17: 87-95

Madrid, J., Hernandez, F., Garcia, V., Orengo, J., Magias, D. and Savilla, V. 2003. Effect of plant extracts on ileal apparent digestibility and carcass yield in broilers at level of farm. 14thEuropean Symp. Poultry Nutrition; August 10-14, Norway. pp. 187-188.

Marcinčák, S., Popelka, P., Martonová, M., Šimková, J. 2010. Vplyv rastlinných aditív na rastové parametre brojlerových kurčiat. In Krmivářství, 6: 11-12.

Matasyoh, L. G., Matasyoh, J. C., Wachria, F. N. Kinyua M. G., Mingai Thairu, A. W., Mukiama, T. K. 2007. Chemical Composition and Antimicrobial Activity of the Essential Oil of Ocimum gratissimum $\mathrm{L}$ growing in Eastern Kenya. African Journal of Biotechnology. 6(6): 760-765.

McMullin, P. 2000. The future of antimicrobial growth promoter alternative for poultry production. In the new millennium. International poultry production volume 8 ,
Number 7, P.30.

Mirzaei, F. and Hari Venkatesh, K. R. 2012. Efficacy of phyto medicines as supplement in feeding practices on ruminant's performance: a review. Global Journal of Research Volume 1, Issue 9391-403.

Nakamura, C. V., Nakamura, T. V., Bando, E., Melo, A. F. N., Cortez, D. A. G. and Ficho, B. O. 1999. Antibacterial activities of ocimum gratissimum. L. essential oil. Mem. Inst. Oswaldo. Guzi 94: 675-678.

Nnabugwu, C. C. 2010. Evaluation of the Feed Preservative Potentials of Ocimum gratissimum L. (Scent leaf). Student Project Dept. of Animal Sci. and Tech. FUTO, Owerri.

Odoemelam, V. U., Nwaogu, K. O., Ukachukwu, S. N., Esonu, B. O., Okoli，I.C., Etuk, E.B., Ndelekwute, E. K., Etuk, I. F., Ogbuewu, I. P. and Kadurumba, O. E. 2012. Performance of Broiler Chickens Fed Ocimum gratissimum L. Supplemented Diets. Proc. 6th Ann. Conf. Nig. Soc. for Indigenous Knowledge and Devpt. (NSIKAD). June 5th -7th MOUA, Umudike. Pp. 15-16.

Onajobi, F. D. 1986. Smooth Muscle Contracting Lipid-soluble Principles in Chromatographic Fraction of Ocimum gratissimum. Journal of Ethnopharmacol. 18: 3 11.

Rai, V., Lyer, U. and Mani, U.V. 1997. Effect of Tulasi Ocimum sanctum leaf powder supplementation on blood sugar levels serum lipids and tissue lipids in diabetic rats. Plant Foods Human Nut. 50: 9-16.

SAS, 2001. SAS User's Guide. Version 
Effect of the inclusion of scent leaf (ocimum gratissimum) in diet on growth and haematology of growing rabbits

6.11. SAS Institute, Inc. Cary, NC.

Václavková, E., Lustyková, A. 2010.

Fytogénní krmná aditiva ve výživě

monogastru. In Krmivář́ství, Vol. 6, .

$9-10$.

Received: $20^{\text {th }}$ September, 2016

Accepted: $23^{\text {rd }}$ February, 2017 